\title{
Whey protein active films incorporated with a blend of essential oils: Characterization and effectiveness
}

\author{
Regiane Ribeiro-Santos ${ }^{1,2}$ | Nathália Ramos de Melo ${ }^{2,3}$ | Mariana Andrade ${ }^{1,4}$ | \\ Gabriela Azevedo ${ }^{5}$ | Ana Vera Machado ${ }^{5}$ | Denise Carvalho-Costa ${ }^{1}$ | Ana Sanches-Silva ${ }^{6,7}$
}

\author{
${ }^{1}$ Department of Food and Nutrition, National \\ Institute of Health Dr. Ricardo Jorge, I.P, \\ Lisbon, Portugal \\ ${ }^{2}$ Department of Food Technology, Institute of \\ Technology, Federal Rural University of Rio de \\ Janeiro, Seropédica, Brazil \\ ${ }^{3}$ Department of Agribusiness Engineering \\ Federal Fluminense University-Volta \\ Redonda, Rio de Janeiro, Brazil \\ ${ }^{4}$ Faculty of Sciences, University of Lisbon, \\ Lisbon, Portugal \\ ${ }^{5}$ Institute for Polymers and Composites/I3N, \\ University of Minho, Campus de Azurém, \\ Guimarães, Portugal \\ ${ }^{6}$ National Institute of Agrarian and Veterinary \\ Research (INIAV), Vairão, Vila do Conde, \\ Portugal \\ ${ }^{7}$ Animal Science Studies Centre (CECA), \\ University of Oporto, Oporto, Portugal

\section{Correspondence} \\ Ana Sanches Silva, National Institute of \\ Agrarian and Veterinary Research (INIAV), Rua \\ dos Lágidos, Lugar da Madalena, 4485-655 \\ Vairão, Portugal. \\ Email: ana.silva@iniav.pt; anateress@gmail. \\ com

\section{Funding information} \\ Brazilian Federal Agency for Support and \\ Evaluation of Graduate Education (CAPES).; \\ National Council for Scientific Research \\ (CNPq); Carlos Chagas Filho Foundation for \\ Research Support of the State of Rio de \\ Janeiro (FAPERJ); National Institute of Health \\ Dr Ricardo Jorge, Grant/Award Number: \\ 2012DAN807; National Council for Scientific \\ Research; Carlos Chagas Filho Foundation for \\ Research Support of the State of Rio de \\ Janeiro; National Institute of Health Dr \\ Ricardo Jorge, I.P., Grant/Award Number:
} 2012DAN807
Whey protein concentrate (WPC) films incorporated with a blend of Cinnamomum cassia, Cinnamomum zeylanicum, and Rosmarinus officinalis essential oils were characterized and evaluated for their effectiveness as an antioxidant for food applications. The effect of the incorporation of essential oils (EOs) at different concentrations (1, 2, 2.7, and 5\% w/w) in WPC were studied by measuring their physical, optical, mechanical, and microstructural properties, in order to evaluate their behavior as a food packaging. The effectiveness of these active WPC films as a packaged was evaluated using a fatty food model (salami). The state of the salami oxidation was measured by the TBARs and hexanal assays during 180 days of storage. A yellowish characteristic color and opacity of WPC-based films tend to increase with the increase of the EO concentration in the film formulation. While films containing 1 and $2 \%$ of EOs showed to be the most hydrophobic and present the lowest moisture content and solubility in water, films with higher EOs $\%(2,2.7$, and $5 \%, w / w)$ presented the highest water vapor transmission rate. The developed WPC active films showed to be heterogeneous, presenting cracks and pores due to the weakening of the polymer chain interaction forces by the EOs, which affected their mechanical behavior. WPC films incorporated with EOs may retard lipid oxidation induced by UV light in food. Besides, they showed to be very effective in the reduction of lipid oxidation in a previous assay with salami, with a longer storage time.

\section{KEYWORDS}

active food packaging, cinnamon, lipid oxidation, rosemary, whey protein films

\section{1 | INTRODUCTION}

The demand for packaged food has increased due to the population growth and the globalization phenomenon, encouraging the food industry to develop new packages and new ways to protect foods against internal and external factors and to prolong the shelf life of foods. ${ }^{1}$ Biopolymers from renewable sources, such as whey protein concentrate (WPC), have been investigated towards the development of packaging materials so that might replace synthetic polymers. WP is a by-product of the dairy industry used in infant formulae and in 
sports supplementation. Consequently, WPC-based films, besides being an edible product, are biodegradable and, by extension, environmental friendly. These films have been reported to have good oxygen and aroma barriers at relatively low humidity. In addition, they are transparent and flexible. Their efficiency is only compromised against moisture because whey protein is a hydrophilic protein. ${ }^{2,3}$

With technology advances, active packaging has emerged. This type of packaging interacts with the product and is intended to extend its shelf life, maintaining or improving the properties of the packaged food. The packaging materials used in these systems can be designed so that certain components can be incorporated. Thus, the substances responsible for the active function of packaging might be directly incorporated into the packaging material. ${ }^{4,5}$

Several substances can be responsible for the active function of packaging, such as essential oils (EOs). ${ }^{6,7}$ They may be used as food additives to prolong the shelf life and maintain the food's quality for an extended period of time. EOs can be extracted from all parts of aromatic plants and are characterized by having a strong sensorial impact, making difficult their direct application into foods. ${ }^{8} \mathrm{An}$ EO is composed by a complex mixture of volatile compounds with several biological properties, such as antioxidant and antimicrobial activities. ${ }^{9,10}$ The use of EOs in food may reduce or replace the application of synthetic antioxidants meeting the consumers' demand for more natural products. ${ }^{11}$ Rosemary and cinnamon EOs are natural preservatives with highly interesting biological properties such as antioxidant and antimicrobial activities, and they have been approved by the FDA and the European Commission as natural food additives. ${ }^{2,11-15}$

The incorporation of these oils in an edible and biodegradable WPC film can be an effective method in the protection of foods against lipid oxidation, which is responsible for loss of food quality, especially in fatty foodstuffs. Lipid oxidation reactions can alter the organoleptic properties of foods, leading to the formation of unpleasant flavours and/or odours and potential toxic compounds. Lipid oxidation also changes the nutritional value and reduces the shelf life of products. ${ }^{16}$

The lipid oxidation can be assessed by the determination and quantification of the formed oxidation compounds, such as malonaldehyde (MDA), formed as a result of the fat acids degradation, and volatile compounds such as hexanal, correlated with flavor modifications. The thiobarbituric acid reactive substances (TBARS) assay is based on the spectrophotometric measurement of a complex formed by the reaction between TBA and MDA. On the other hand, hexanal is an aldehyde formed during lipid oxidation, considered to be an indicator of this natural chemical reaction once it is the dominant formed aldehyde. Hexanal is the aldehyde responsible for the organoleptic changes in fatty foods. Both methods are widely used to evaluate the extent of lipid oxidation in meat products. ${ }^{17-20}$

Several EOs were incorporated in packages for food applications as antimicrobial and antioxidant agents, such as winter savory, cinnamon, oregano, clove, pimento, lemon, thymes, ginger, turmeric, plai, and rosemary. ${ }^{21-26}$ In addition, the combinations of EOs may increase their spectrum of action due the possibility of synergism, resulting in the most effective package in the protection of foods against lipid oxidation and microbial contamination. ${ }^{26}$

The objective of this work is the incorporation of a blend of 2 cinnamon species (Cinnamomum cassia and Cinnamomum zeylanicum) and rosemary (Rosmarinus officinalis) EOs in a WPC-based film with the purpose of increasing the shelf life of a processed meat product, salami. Characterization of the active films was carried out by evaluation of their physical, optical, mechanical, and microstructural properties. The effectiveness of the new active film against lipid oxidation was evaluated by the TBARS assay and monitorization of hexanal content during food storage.

\section{2 | MATERIAL AND METHODS}

\section{1 | Material}

Whey protein concentrate $(82.80 \%$ protein) was obtained from Glanbia Nutritionals (Fitchburg, USA), and glycerol was acquired from Sigma-Aldrich (Madrid, Spain).

Cinnamon (C. zeylanicum Blume and C. cassia (L.) J. Presl) and rosemary ( $R$. officinalis L.) EOs extracted by distillation method were purchased from Ferquima ${ }^{\circledR}$ (Ferquima Indústria e Comércio Ltda, Vargem Grande Paulista, São Paulo). The blend of these EOs was composed by $51 \%$ of $C$. zeylanicum, $34 \%$ of $C$. cassia, and $15 \%$ of $R$. officinalis and stored in a dark container at $5{ }^{\circ} \mathrm{C}$ until used. ${ }^{27}$

The sliced salami (approximately $7 \mathrm{~cm}$ of diameter and $0.35 \mathrm{~cm}$ of thickness) was obtained from a local store in Lisbon, Portugal, and stored, protected from light, at $-20^{\circ} \mathrm{C}$ until used.

In order to have a sample as homogeneous as possible and because the whey protein films were not made on the same day, all the salami slices had to be frozen until further use in other to preserve their nutritional value and their oxidative state. Only the quantities of salami slices required for wrapped with the WPC films were unfrozen.

\subsection{Whey protein-based active film preparation}

A solution was prepared by WPC ( $8 \%, \mathrm{w} / \mathrm{w}$ of protein) homogenization under continuous magnetic stirring in distilled water, following the procedure reported by Bahram et al (2013), with adaptations. ${ }^{2}$ The $\mathrm{pH}$ was adjusted to 7.0, using $1 \mathrm{M} \mathrm{NaOH}$. Subsequently, the solution was heated in a water bath (Memmert, Schwa bach, Germany) at $80^{\circ} \mathrm{C}$ for 30 minutes to denature the protein. The solution was rapidly cooled to room temperature $\left(+/-23^{\circ} \mathrm{C}\right)$ in an ice-water bath. Glycerol was added at ratio of 1:1 (protein:glycerol) and mixed into the solution. Afterwards, the blend of EOs at 1, 2, 2.7, or $5 \%(w / w)$ was added to the formulation and homogenized using an Ultra-Turrax (IKA DI 25 basic, Werke GmbH \& Co, Germany) at 14000 rpm for 2 minutes. Finally, $130 \mathrm{~mL}$ of each solution was cast on the center of $37 \times 26 \mathrm{~cm}$ Teflon ${ }^{\circledR}$ coated plates then dried by solvent evaporation for 48 hours at room temperature (approximately $23-25^{\circ} \mathrm{C}$ ) and room relative humidity. Films were removed from the plates and immediately used. A film without added EOs was used as control.

\subsection{Characterization of the active WPC films}

Five films from whey protein were made: WPO (control, without EOs), WP1 (with 1\% of EO blend), WP2 (with 2\% of EO blend), WP 2.7 (with $2.7 \%$ of EO blend), and WP5 (with 5\% of EO blend). 


\subsection{1 | Film thickness}

Film thickness was measured using a hand-held digital micrometer (Mitutoyo No. 547-301, Tokyo, Japan). The reported values are the average of, at least, 5 random readings on each film sample.

\subsubsection{Film moisture content and solubility in water}

The moisture content $(\mathrm{MC})$ of the protein films was determined by their weight change. Thus, film samples $(0.2 \mathrm{~g})$ were weighed and placed on Petri dishes and, before and after, oven drying at $105^{\circ} \mathrm{C}$, under forced air circulation for 24 hours. MC values were determined as the initial percentage of the film weight lost during drying and was reported on wet basis as Gounga, Xu, and Wang (2007). ${ }^{28}$

To determine the solubility of the films in water (SW \%), a method reported by Gounga, Xu, and Wang (2007) was used, with adaptations. ${ }^{28}$ Samples of films (0.2-g dry matter) were immersed in $40 \mathrm{~mL}$ of distilled water for 24 hours at room temperature. The insolubilized films were filtered using a Whatman $n^{\circ} 1$ filter paper. The filter paper plus undissolved pieces of films were dried in air-circulating oven (105 ${ }^{\circ} \mathrm{C}$ for 24 hours) to the constant final dry weight. Values of the film solubility in water were determined in triplicate for each treatment and calculated using the following equation:

$$
\text { Solubility in water }(\%)=(W i-W f) \times 100 / W i
$$

where $W_{i}=$ initial dry film weight $(g)$ and $W_{f}=$ final dry film weight $(g)$.

\subsection{3 | Light transmission and film transparency}

The ultraviolet (UV) and visible light barrier properties of the films were measured on dried films at selected wavelengths between 200 and $800 \mathrm{~nm}$, using a UV-VIS spectrophotometer (Shimadzu UV-2401 PC, Japan) based on the procedure described by Han and Floros (1997). ${ }^{29}$

Transparency of the films was determined at $600 \mathrm{~nm}$ and calculated by Equation 2 .

$$
\text { Transparency }=\frac{A_{600}}{X}
$$

where $A_{600}$ is the absorbance at $600 \mathrm{~nm}$, and $X$ is the film thickness $(\mathrm{mm})$. At least 5 strips of each film type were tested. The greater transparency value shows the lower transparency of film.

\subsection{4 | Film color}

Color of films at the air surface was determined with a UV-VIS spectrophotometer (Shimadzu UV-2401 PC, Japan), using the CIELab color scale employed to measure the degree of lightness ( $L$ ), redness ( $+a)$ or greenness $(-a)$, and yellowness $(+b)$ or blueness $(-b)$ of the films, under $\mathrm{D}_{65}$ (daylight) at $10^{\circ}$ (viewer conditions). $\mathrm{L}^{*}$, $\mathrm{a}^{*}$, and $\mathrm{b}^{*}$ values were averaged from 5 readings for each sample; total color difference $(\Delta \mathrm{E})$ and whiteness index $(\mathrm{WI})$ were calculated according to Equations 3 and 4 , respectively. At least 5 strips of each film were analyzed.

$$
\begin{gathered}
\Delta E=\sqrt{\left(\Delta L^{*}\right)^{2}+\left(\Delta a^{*}\right)^{2}+\left(\Delta b^{*}\right)^{2}} \\
W I=100-\sqrt{\left(100-L^{*}\right)^{2}+a^{* 2}+b^{* 2}}
\end{gathered}
$$

where, $\Delta L^{*}, \Delta a^{*}$, and $\Delta b^{*}$ are the differentials between a sample color values with EO and the film control (without EO).

\subsection{5 | Contact angle measurement}

Contact angle (CA) of films is one of the indicators of hydrophilicity and hydrophobicity. The CA value is used to estimate the resistance of the films to water ${ }^{30}$ : the higher the CA value, the higher is the surface hydrophobicity. ${ }^{31,32}$ According to Vogler (1998), hydrophobic surfaces are those that $\theta>65^{\circ}$ whereas, hydrophilic surfaces $\theta<65^{\circ}$. ${ }^{33}$

The CA was used to estimate the surface hydrophobicity of the films, and it was measured using a goniometer (Contact angle system OCA 20 Dataphysics, Gemany). Contact angle measurement of the water on a horizontal film surface was carried out using an image software. Distilled water $(3 \mu \mathrm{L})$ was dropped on the film surfaces with a precision syringe. The image of the drop, initial (taken by 0 second) was recorded with a video camera. At least 6 measurements per film were carried out and the mean value taken.

\subsubsection{Water vapor transmission rate}

Water vapor transmission rate (WVTR) of films was gravimetrically determined by ASTM E96-00. ${ }^{34}$ The films were cut into circles with a diameter slightly larger than the diameter of special circular aluminum cups, with diameter of $7 \mathrm{~cm}$ and a depth of $1 \mathrm{~cm}$. The cup was filled with anhydrous calcium chloride desiccant $(0 \% \mathrm{RH})$ and covered with the film disc. The film was sealed onto an aluminum cup with paraffin to hold the film in place. The whole system was then placed in a desiccator, equilibrated at $75 \% \mathrm{RH}$, containing a saturated sodium chloride solution. The cups were weighed at certain intervals of time, and linear regression analysis of weight gain versus time (day) was plotted to obtain the slope $\left(r^{2} \geq 0.99\right)$. The measured WVTR of the films was calculated using Equation 5.

$$
\text { WVTR }\left(\text { g water } /\left(\mathrm{m}^{2} \text { day }\right)\right)=\frac{G}{t X A}
$$

where $G / t$ (g water / day) is the slope (weight versus time plot) and A is effective film area $\left(\mathrm{m}^{2}\right)$. WVTR was measured for 3 independent samples of each film $(n=3)$.

\subsection{7 | Mechanical properties}

Tensile strength (TS) and elongation at breaking (EB) of whey proteinbased films were determined according to the ASTM standard test method D 882-02, ${ }^{35}$ using a Zwick/Roell (Ulm, Germany) with a 50$\mathrm{KN}$ load cell and speed of $5 \mathrm{~mm} / \mathrm{s}$. The films were cut into rectangular strips (150 mm $\times 10 \mathrm{~mm}$ ), and their thickness was measured at 10 points. The films were held parallel with an initial grip separation of $100 \mathrm{~mm}$. The analysis was performed at room temperature (approximately $25^{\circ} \mathrm{C}$ ). This measurement was repeated at least 5 times $(n>5)$ for each film, and the mean values were reported.

\subsection{8 | Film microstructure using scanning electron microscopy (SEM)}

An Ultra-high resolution Field Emission Gun Scanning Electron Microscopy (NOVA 200 Nano SEM, FEl Company) was used to examine the morphology of whey protein-based films with and without EOs. The pieces were cut from the films, covered with a very thin film $(8 \mathrm{~nm})$ of gold-palladium (80-20 weight \%), using a high-resolution sputter coater (208HR Cressington Company) coupled to a MTM-20 
Cressington High Resolution Thickness Controller. All the specimens were examined by Secondary Electron Images (SE) at an acceleration voltage of $10 \mathrm{kV}$. The films were observed a magnification of $1000 \times$ (surfaces) and $800 \times, 1500 \times$, and $2000 \times$ (cross sections).

\subsection{9 | Fourier transform infrared (FTIR) analysis}

The spectra of the films were obtained under attenuated total reflectance (ART) mode at wavenumber range of $400-4000 \mathrm{~cm}^{-1}$ at a resolution of $4 \mathrm{~cm}^{-1}$ using a Fourier transform infrared spectrometer (JASCO FT/IR-4700). Prior to analysis, film samples were conditioned in a desiccator containing silica gel for 2 weeks at room temperature to obtain the dehydrated films. The spectra were recorded on absorbance mode, and for each spectrum, 64 scans were co-added. Three replicates were collected for each film surface sample.

\section{4 | Packaging of salami}

The salami present an average composition varied from of 31 to $59 \%$ for fat content, 4.7 to 6.6 for $\mathrm{pH}$, and 0.780 to 0.970 for water activity. $^{36}$

The studied salami was from a commercial brand. The salami presented the following ingredients: pork, pork loin, gelatin, milk powder, corn syrup glucose, soy protein, spices, and salt. In its constitution, some food additives were present: E-250 (sodium nitrite), E-252 (potassium nitrate), E-316 (sodium erythorbate), and E-120 (carminic acid). The nutritional value was (for $100 \mathrm{~g}$ ) $352.7 \mathrm{kcal}, 23.5 \mathrm{~g}$ protein, $26.5 \mathrm{~g}$ of total lipids, $4.9 \mathrm{~g}$ of carbohydrates, and $3.9 \mathrm{~g}$ of salt.

All salami slices had the same freezing conditions to avoid any possible changes $\left(-20^{\circ} \mathrm{C}\right)$. The necessary slices were unfreeze for use, and, after packed with the active film, the salami was refrigerated $\left(5^{\circ} \mathrm{C}\right)$.

Salami slices (approximately with $10 \mathrm{~g}$ each slice, $7 \mathrm{~cm}$ of diameter, and $0.35 \mathrm{~cm}$ of thickness) were wrapped (film-salami-film) with WP films containing different amounts of EO blend: control film (without EO blend) and films with 1, 2, 2.7, and $5 \%(\mathrm{w} / \mathrm{w})$ of EO blend. The active film (thickness ranging from 0.34 to $0.45 \mathrm{~mm}$ depending on the concentration of the EO in the films) had the same size of the salami slices, and they were placed on both sides of the salami slice. The salami wrapped in WPC film was also vacuum packed in bags of polyethylene (PE). PE bags are flexible and transparent, present high water vapor, and no good gases $\left(\mathrm{CO}_{2}, \mathrm{O}_{2}, \mathrm{~N}_{2}\right)$ barrier properties. $\mathrm{PE}$ bags are permeable to oil and fat. ${ }^{37}$

All prepared samples were stored at $5{ }^{\circ} \mathrm{C}$, protected from light. The samples were analyzed at $t=0,4,7,15,30,45,60,90,135$, and 180 days for evaluation of oxidation status of salami packaged with WP films incorporated with EO blend.

\section{5 | Effectiveness of the active films against lipid oxidation}

\subsection{1 | Hexanal assay}

Hexanal extraction was accomplished according to the method used by Wen et al (1997). ${ }^{38}$ Hexanal identification and quantification were performed with an Ultra High Performance Liquid Chromatography coupled with a Diode-Array Detection (UHPLC-DAD), method adapted from Sanches-Silva et al (2004). For hexanal extraction, salami (1 g) was homogenized using an Ultra-Turrax (IKA DI 25 basic, Werke $\mathrm{GmbH} \&$ \& Co, Germany) with $5 \mathrm{~mL}$ of solution of 2,4dinitrophenylhydrazine (2,4-DNPH) in sulfuric acid. The homogenate was then left to stand in the dark for 4 hours to complete the reaction. After, an extraction with $10 \mathrm{~mL}$ of hexane was performed for 3 times, and the pooled hexane was evaporated to dryness. The residue was reconstituted with methanol $(10 \mathrm{~mL})$, filtered, and analyzed by UHPLC-DAD. The analysis was conducted in triplicate. Identification of hexanal was carried out by comparing UHPLC retention time and spectrum with a standard. Concentration of hexanal was determined using a standard curve designed by plotting hexanal concentration versus hexanal area of different standard solutions. The analytical standard used for the construction of the calibration curve was obtained from Sigma-Aldrich $®$ (Madrid, Spain).

\subsubsection{Validation assay of hexanal}

An UHPLC-DAD method was developed and validated for identification and quantification of hexanal in meat products. An ACQUITY ${ }^{\mathrm{TM}}$ UPLC ${ }^{\circ}$ BEH C18 pre-column $(2.1 \times 5 \mathrm{~mm}, 1.7 \mu \mathrm{m}$ particle size $)$ and an AQUITY UPLC $®$ BEH C18 (2.1 mm $\times 50$ mm, 1.7- $\mu \mathrm{m}$ particle size) were used. The mobile phase was a gradient of acetonitrile and ultrapure water $(75: 25, \mathrm{v} / \mathrm{v})$. The hexanal was quantified at the wavelengths of $365 \mathrm{~nm}$, and the run time was 5 minutes. The method was validated regarding the following parameters: linear range, linearity, limit of detection (LOD) and limit of quantification (LOQ), precision (intra and inter-day precision) and accuracy. LOD and LOQ were determined at signal-to-noise ratio of around 3 and 10 , respectively. ${ }^{39}$ Intraday precision was estimated by analyzing 6 samples after extraction in the same say, while inter-day precision was examined by performing extraction of samples in 3 consecutive days. Quantification was achieved with an external standard, based on a calibration line. The line consisted of a plot of peak area of hexanal against the concentration of different calibration solutions. Each solution was injected in duplicate in the chromatographic system under optimized condition. For the evaluation of the recovery of hexanal, samples were analyzed before and after addition of a known concentration of hexanal. Six independent samples were spiked with a concentration of $200 \mu \mathrm{g}$ hexanal/100 g salami Average recoveries were calibrated by the formula recovery $(\%)=\{$ (amount in the spiked sample - amount in the non-spiked sample) / added amount $3 \times 100$.

\subsubsection{Thiobarbituric acid reactive substances (TBARS) assay}

TBARS assay was based on the spectrophotometric measurement of a complex formed by the reaction between thiobarbituric acid (TBA) and malondialdehyde (MDA), according to the method of Miller (1998). ${ }^{40}$ Malondialdehyde (MDA) is formed due to the degradation of polyunsaturated fatty acids; therefore, this assay measures the oxidative status of a sample. Packaged salami ( $5 \mathrm{~g}$ ) was homogenized with $50 \mathrm{~mL}$ of trichloroacetic acid (10\%) in $0.02 \mathrm{M}$ of orthophosphoric acid, using an Ultra-Turrax (IKA DI 25 basic, Werke GmbH \& Co, Germany). Then, the solution was filtered through filter paper (Whatman $n^{\circ} 1$ ). The filtered solution ( $5 \mathrm{~mL}$ ) was homogenized with $5 \mathrm{~mL}$ of TBA aqueous solution $0.02 \mathrm{M}$ and heated at $100{ }^{\circ} \mathrm{C}$ for 40 minutes. Afterwards, solutions 
were cooled down for 10 minutes, and the concentration of the coloured pigment produced was calculated by measuring the absorbance at $530 \mathrm{~nm}$. A standard curve of 1,1,3,3-tetraethoxypropane (TEP) was prepared with concentrations ranging from 0 to $5 \mu \mathrm{g} \mathrm{mL} \mathrm{L}^{-1}$. Results were expressed in mg MDA per kg of salami (mg MDA kg-1).

\section{6 | Statistical analysis}

Results were expressed as means \pm standard deviation of at least 3 replicates. Differences among samples were tested by analysis of variance (ANOVA) followed by Tukey's test. All statistical analyses were tested at 0.05 level of probability, using the software STATISTICA $\AA$ 10.0 (Statsoft Inc. 2325, Tusla, OK).

\section{3 | RESULTS AND DISCUSSION}

\subsection{Whey protein-based active film}

WP films without EOs were transparent, uniform, flexible, and had smooth surfaces without visible pores or cracks. Films with EOs showed a yellow color that was intensified, as well as the strong aroma, while the transparency decreased (more opaque) as the EO blend concentration increases.

Control film (without EOs) and films with the EO blend were easily removed from the casting plates. The appearance of the 2 sides of the films was different in both films. The film side facing the casting plates was dull while the other one was shiny. Differences in the both sides of films were also reported, in previous studies, by Kokoszka et al (2010) ${ }^{41}$ and Ramos et al $(2012 ; 2013)^{42,43}$ for the same whey protein-based films. According to Ramos et al (2012), this difference may be due to a phase separation during the drying process of the films. ${ }^{42}$

After contact with the salami, the films presented points of reddish color that is a feature of the packaged product.

\subsection{Characterization of the active films}

\subsection{1 | Microstructure properties}

Figure 1 shows SEM micrographs of surfaces and cross sections of WPC films with the EO blend, at different levels, in their formulation. Different structures are formed at the top and bottom, compared with the center (cross sections) of each film.

The cross section of the control film (without EOs) presented uneven microstructure and a surface covered with micro-pores and cracks, which can be attributed to the preparation process of the film (Figure 1A-C). Additionally, the upper surface (contact with air) showed numerous small holes and small cracks. As the water evaporates at the top, faster drying rates result in a structure with smaller pores $^{44}$ (Figure $1 \mathrm{~A}-\mathrm{C}$ ). While lower surface (in contact with the casting dish) exhibited roughness's as well as smaller pores.

Nevertheless, the microstructure of the films containing EO blend showed many pores and surface structure (Figure 1D-K), which might be attributed to the evaporation of the EOs during the drying process. In fact, these spaces were filled by EO blend, which evaporated from the surface, as observed also by Jouki et al (2014). ${ }^{45}$ It could be responsible for increasing moisture permeability through the film.
Pores and cracks were more evident in the film with $5 \%$ of EO blend. Due to this, the water vapor diffusion was favored, reducing the barrier to water vapor in this film. Bahram et al (2014) reported the same structure for WPC-based film containing cinnamon EO. ${ }^{2}$

Additionally, film with the EO blend had heterogeneous and rougher surface, with discontinuities associated with the formation of 2 phases (protein and lipid) in the matrix, indicating a lack of integrity due to weaker protein-EO interactions and miscibility between the film network and other components. ${ }^{46}$ Similar observations were made for WPI-based film incorporated with almond and walnut oils. ${ }^{3}$ At low oil concentration, the effect of the overall increase in the hydrophobic nature of the matrix could prevail over the effect of the loss of matrix cohesion, whereas did not occur at high EO content. ${ }^{46}$ The higher irregular character of film surface may also be associated with the molecular aggregation of lipid molecules during the drying step that occurs upon increased oil content. ${ }^{3}$

The film cross section showed that EO droplet to the coarser shape is focused on the air side of films for all films with EOs, indicating the lack of integrity between EO molecules and WPC, as well as showing that emulsifying nature of the protein was not sufficient to stabilize oil droplets in the film-forming emulsions (oil upper surface); this is evident in Figure 1G.

It was also observed that the number of oil particles accumulated increased at the highest EO blend content. This is related to the flocculation of oil particles on the surface of films. This phenomenon was also related by Atef, Rezaei, and Behrooz (2015) in agar-cellulose bionanocomposite films with savory EO. ${ }^{47}$ In addition, when oil concentration increased in the formulation, the polymer chains might be weakened because of greater molecular contact between the film solution and EOs, making the matrix more open, and consequently creating cracks in the sample. This could increase WVTR and decrease TS of the films. ${ }^{46}$

The oil globules are more concentrated on the air side, because film retraction during drying induces changes in its structure, which becomes denser, and the oil migrates towards the air side, favoring aggregation and coalescence. Not using emulsifier allows greater emulsion destabilization during drying, favoring oil migration towards the surface, and tending to form a bilayer-type film. ${ }^{41}$

The oil is not well distributed throughout the film on both sides. A clear difference between the 2 sides of film (lower surface and upper surface) can be noticed. Different surfaces are commonly observed if the films that have been dried in contact with air, with the bottom of the films in contact with the casting support essentially smooth while the top surface is usually rougher due to the drying process occurring in contact with the air. ${ }^{46}$

Essential oil particle size and their distribution are affected by the type of EO/EO blend and the amount used, according with Peng and $\mathrm{Li}$ (2014). ${ }^{26}$ Galus and Kadzińska (2016) reported that the particle size increases with the films with a higher oil percentage. On the homogenization process, the WPI forms a foam that, due to the presence of the oils, decreases and, in consequence, the migration of the oils particles increases causing a higher heterogeneity on protein matrix films. ${ }^{3}$ Fourier transform infrared (FTIR) analyses are presented in Figure 2. Films with and without the addition of different EO blend levels showed the similar major peaks, but the amplitudes of peaks varied. 

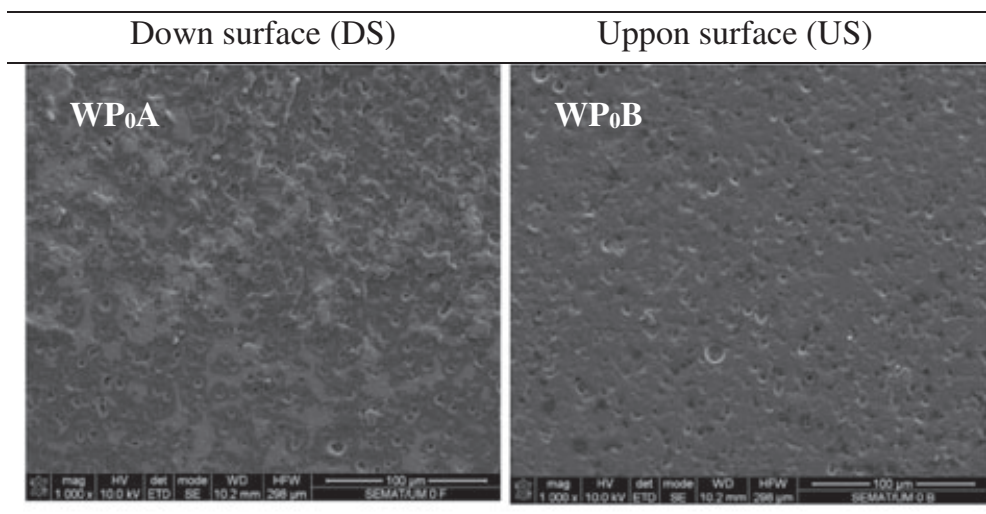

Not shown
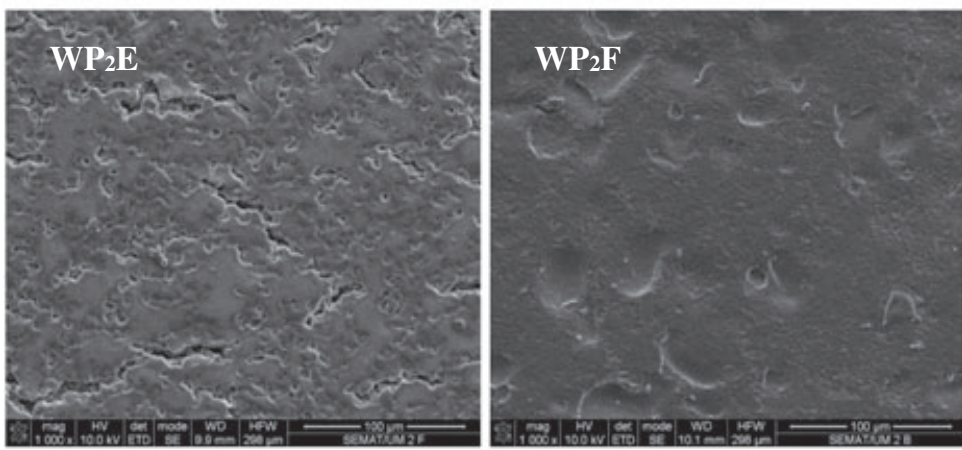

Not shown
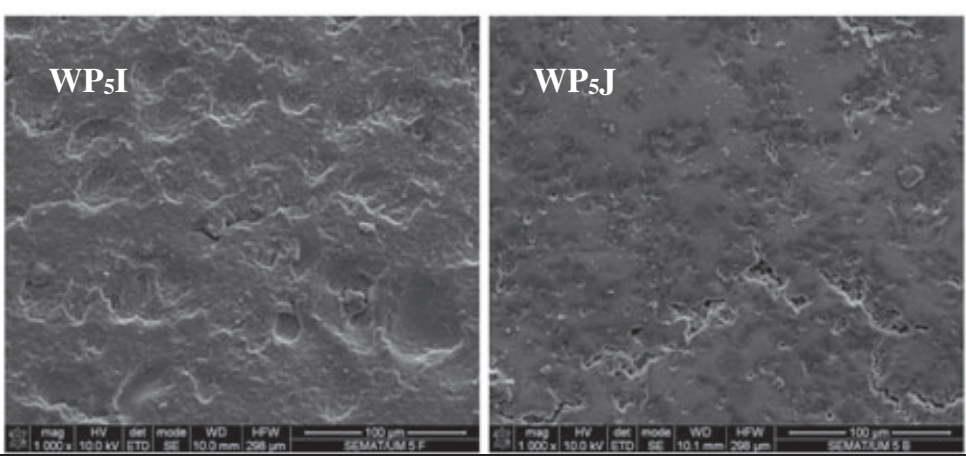

Cross sections (CS)

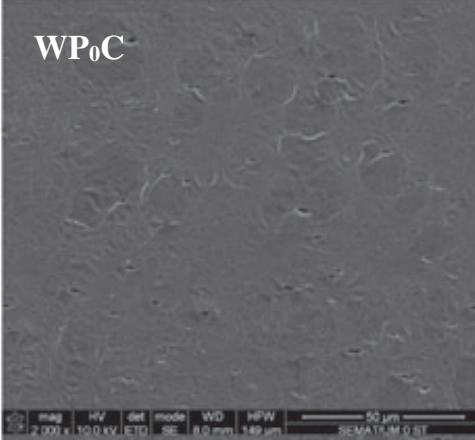

$\mathrm{WP}_{1} \mathrm{D}$

Not shown
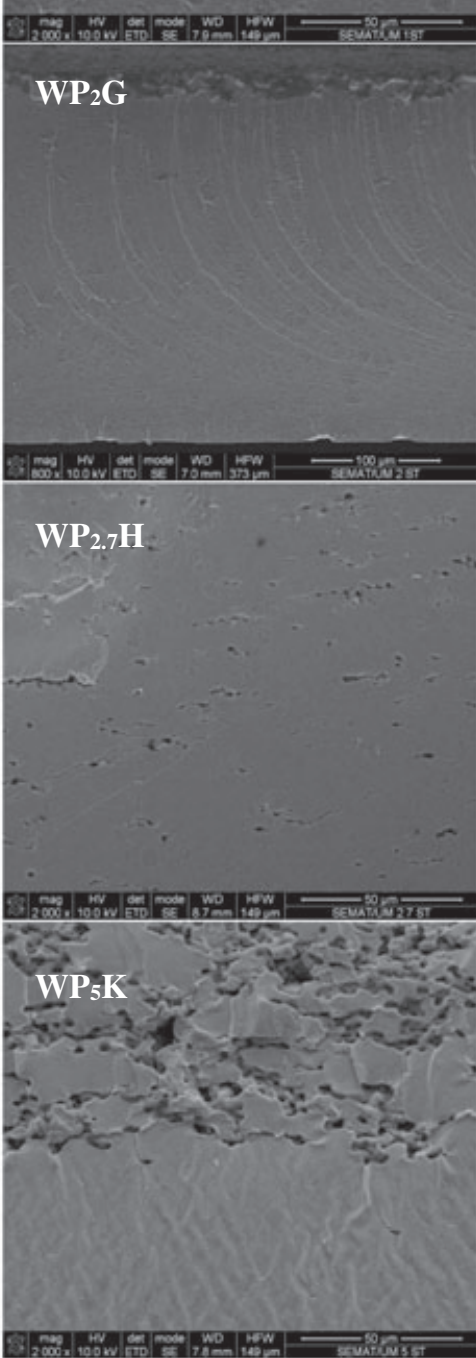

FIGURE 1 Scanning electron microscopic images of cross sections (magnification 2000x exception film 2\%, 800x) and surfaces (magnification $1000 \times$ ) both side of whey protein film. $W P_{0} A, B$ and $C$ film without EO blend; $W P_{1} D$ film with $1 \%$ of EO blend; $W P_{2} E, F$, and $G$ film with $2 \%$ of $\mathrm{EO}$ blend, $\mathrm{WP}_{2.7} \mathrm{H}$ film with $2.7 \%$ of $\mathrm{EO}$ blend; $\mathrm{WP}_{5} \mathrm{l}, \mathrm{J}$, and $\mathrm{K}$ film with $5 \%$ of $\mathrm{EO}$ blend 


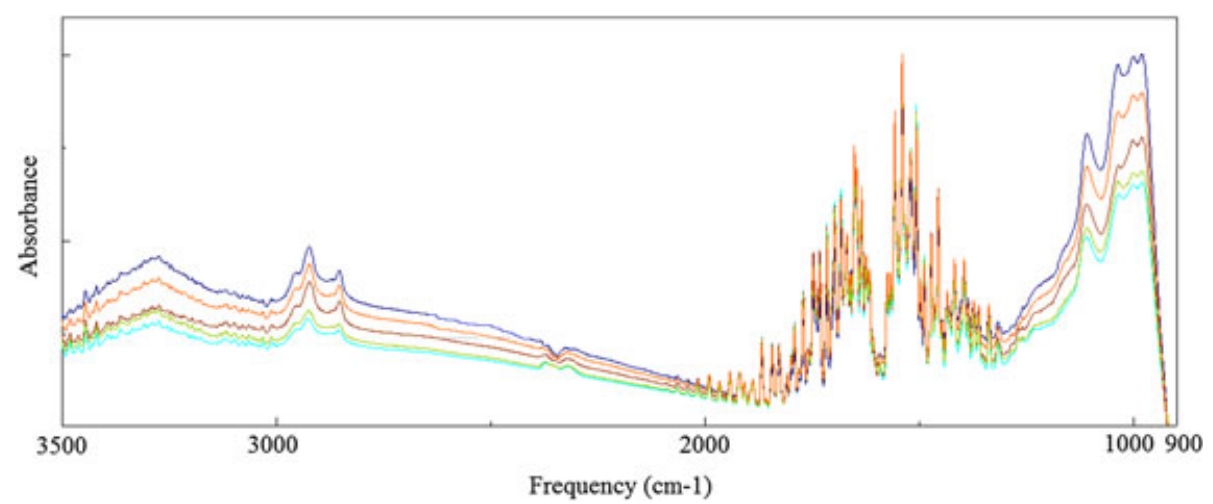

FIGURE 2 FTIR absorbance spectra of control film (without essential oil) and WP film incorporated with 1, 2, 2.7, and 5\% (w/w) of essential oils blend

The peak between 3000 and $3600 \mathrm{~cm}^{-1}$ is associated to stretching vibration of hydroxyl from glycerol and phenol and stretching of $\mathrm{N}-\mathrm{H}$ groups from protein. ${ }^{48-50}$ The spectral region was characterized by broad absorption band at $3274.54 \mathrm{~cm}^{-1}$ for all protein films, control, and active film with the EO blend at different levels. The band of $\mathrm{N}-\mathrm{H}$ stretching mode is generally at $3254 \mathrm{~cm}^{-1,51}$ therefore, there was a displacement of the band that could be due to the presence of other components in the biofilm formulation as glycerol. ${ }^{48}$

Spectral region between 2850 and $2980 \mathrm{~cm}^{-1}$ are typical of stretching vibrations of the $\mathrm{C}-\mathrm{H}$ bond. ${ }^{49}$

In this study, several bands were observed in the region at 1652 to $1540 \mathrm{~cm}^{-1}$, being assigned to strong vibrations of amide I and II. The absorption bands seen between 1600 and $1700 \mathrm{~cm}^{-1}$ correspond to the presence of amide I, which is sensitive to the secondary structure of the protein and is mainly governed by stretching vibration of $\mathrm{CO}$ and $\mathrm{C}-\mathrm{N}$ groups, thus being attributed to absorption bands of protein. While, spectral region between 1400 and $1550 \mathrm{~cm}^{-1}$ is associated to $\mathrm{N}-\mathrm{H}$ bending (amide II). ${ }^{49,50,52}$

The spectral range at 800 to $1150 \mathrm{~cm}^{-1}$, corresponding to vibrations of $\mathrm{C}-\mathrm{O}$ bonds, is attributed to absorption bands of glycerol and $\mathrm{C}-\mathrm{H}$ in aromatic rings from EOs. ${ }^{50,53}$

\subsection{2 | Physical properties}

Table 1 displays the influence of the incorporation of different levels of EO blend on the thickness, MC, solubility in water (SW), WVTR, and CA of whey protein films.
The thickness of EO films varied between the range of 0.363 and $0.454 \mathrm{~mm}$. The control film presented a thickness of $0.342 \mathrm{~mm}( \pm$ 0.062). The increasing of EO blend concentration increased slightly the film thickness. However, the difference in films thickness was not significant $(P>0.05)$ (Table 1). Thickness affects the drying of the solution of formation of film, and high thickness causes an increase in WVTR. $^{28}$

The hydrophilicity of the control film $\left(\theta=55.07^{\circ}\right)$ is attributed to the water binding capacity of the plasticizer (glycerol) and to the functional groups of protein $\left(\mathrm{OH}\right.$ and $\left.\mathrm{NH}_{2}\right) .{ }^{2,54}$ When the EO blend was added, an increase in CA values was observed $(P<0.05)$, independent of film side, due to the more hydrophobic character of film with the added EO blend (Table 1). Thus, fat content significantly affects the properties of WPC films as was previously reported for whey protein film incorporated with walnut and almond oils ${ }^{3}$ and WPC film activated with cinnamon EO. ${ }^{2}$ WP1 and WP2 exhibit the highest hydrophobicity. In general, CA values decreased with the increase in EO blend content. In spite of the hydrophobic nature of EOs, WP5 showed the lowest hydrophobic character.

WVTR is 1 important parameter to determine the resistance of WPC films against water vapor, in food protection. The hydrophobic nature of EO could have an influence on the properties of polymerbased films enriched with EOs due to decrease the water sorption capacity of the films. ${ }^{2,3,54}$ In this study, WVTR did not exhibit significant differences $(P>0.05)$ when $1 \%$ EO blend was added to WPC film. However, the highest levels of EOs in the film (WP2, WP2.7, and WP5) showed the highest WVTR value (Table 1). According to Atarés et al

TABLE 1 Physical properties of whey protein films containing essential oils blend ${ }^{a}$

\begin{tabular}{|c|c|c|c|c|c|}
\hline EO blend in film, w/w & Thickness, mm & WVTR ${ }^{\mathrm{b}}, \mathrm{g}\left(\mathrm{m}^{-2} \mathrm{day}^{-1}\right)$ & Contact angle ${ }^{c}, \theta$ & Solubility in water, $\%$ & Moisture content, \% \\
\hline $0 \%$ & $0.342 \pm 0.062^{a}$ & $1.742 \pm 0.288^{b}$ & $55.07 \pm 1.61^{\mathrm{c}}$ & $77.247 \pm 0.909^{a}$ & $49.601 \pm 0.332^{c}$ \\
\hline $1 \%$ & $0.363 \pm 0.056^{a}$ & $1.745 \pm 0.223^{b}$ & $71.00 \pm 2.87^{a}$ & $71.286 \pm 1.544^{b}$ & $43.588 \pm 0.370^{e}$ \\
\hline $2.7 \%$ & $0.399 \pm 0.090^{a}$ & $2.931 \pm 0.006^{\mathrm{a}}$ & $65.71 \pm 3.62^{b}$ & $76.856 \pm 0759^{a}$ & $52.173 \pm 0.408^{b}$ \\
\hline $5 \%$ & $0.454 \pm 0.065^{a}$ & $3.805 \pm 0.231^{a}$ & $65.82 \pm 1.05^{b}$ & $78.911 \pm 0.967^{a}$ & $54.794 \pm 0.601^{a}$ \\
\hline
\end{tabular}

Different superscript letters within the same column indicate significant differences from each other $(P<0.05)$.

The analyses were performed at room temperature.

${ }^{b}$ Water vapor transmission rate.

${ }^{\mathrm{c}}$ Contact angle at time 0 of water droplet application. 
(2010), it cannot be assumed that the WVTR of films is reduced simply by adding a hydrophobic component to the formulation. ${ }^{55}$ The extent of reduction of water vapor is strongly depending on the EO type, concentration, and particle size distribution, which can be correlated with homogenization method. As long as the lipid droplets are small and homogeneously distributed within the film thickness, the barrier efficiency of emulsion-based films tends to increase. ${ }^{3,56}$ Additionally, water vapor permeation can also be affected by film microstructure and the presence of pores that could facilitate the water vapor migration, as confirmed by SEM analysis. The distinct compositions of EOs could be responsible for the difference in the WVTR and depends on the hydrophilic-hydrophobic ratio of film components. ${ }^{57}$ Still, the difficulties in integrating the lipid in the hydrophilic network may cause matrix disruptions and create void spaces at the protein-lipid interface. The impact of the lipid addition on the microstructure of the emulsified film is a determining factor in water barrier efficiency. ${ }^{55}$ Due to the greater polarity of EO components, this probably may partially account for the higher solubility of the film incorporated with EO. ${ }^{58,59}$

Solubility in water (SW) is an index of the film hydrophilicity; ${ }^{58}$ it is an indicator of the resistance of the film to water. ${ }^{47}$ The results of SW showed that the films dissolved in water had visual loss in integrity or broke apart after 24 hours of immersion. Plasticizers, as glycerol, increase water solubility of protein film, due their higher hygroscopicity. ${ }^{44}$ This agrees with SW results found for the control film that showed a high solubility. But, films with EO (WP1 and WP2) reduced the $S W$ values due to the presence of oil blend, a hydrophobic component. However, a significant $(P<0.05)$ increase in SW values was observed when adding 2.7 and $5 \%$ of EO blend in the matrix of the WP film that may be attributed to the establishment of protein-EO interactions which weaken the interactions of the polymeric network ${ }^{23}$ and limit the interaction of glycerol with the protein matrix. ${ }^{60} \mathrm{SW}$ values were the highest for films with high EO concentrations (2.7 and $5 \%, w / w)$, exhibiting high hydrophilicity, as confirmed by CA assay, and present higher amount of cracks, observed by microstructure analyses, similar to that reported by Aguirre, Borneo, and Leo (2013) for protein films incorporated with oregano EO. ${ }^{60}$

Moisture content $(\mathrm{MC})$ of WPC films with EO blend is shown in Table 1. MC value reduced significantly $(P<0.05)$ with addition of 1 and $2 \%$ of EO blend with respect to control, as expected, due to the addition of hydrophobic compounds in the polymeric matrix. This is in accordance with the data reported by Shen and Kamdem (2015) in which chitosan film presented reduced moisture after addition of citronella or cedarwood EOs $(10,20$, or $30 \%) .{ }^{61}$ However, increase of EO blend level $(2.7$ and $5 \%)$ increased significantly $(P<0.05)$ the $M C$ values in agreement with the data found by Jouki et al (2014), which showed that incorporation of $2 \%$ of oregano EO in quince seed mucilage film increased $\mathrm{MC}$ values. ${ }^{45}$ This may be attributed to breakup of film network, which increases the amount of water molecules which were present between polymer chains by hydrogen bonding. ${ }^{45}$ As previously observed in the SEM images (Figure 1), the use of high concentrations of EO blend (2.7 and 5\%) creates several cracks or fractures in the films. This enhances water permeability through the film, and thereby increases the MC, as well as, WVTR.

\subsection{3 | Optical properties}

Optical attributes are extremely important in the appearance of film, because they directly influence the consumer's acceptability, contributing to the consumer's willingness to buy a particular food product. In order to compare the differences among prepared films, Tables 2 and 3 report the parameters of light transmission (\%), transparency, and color of the films obtained.

Light transmission, in the UV-Vis range, as well as, transparency of films incorporated with EOs at different concentrations, is displayed in Table 2. All control and active films showed an excellent barrier

TABLE 2 Light transmission (\%) and transparency of whey protein films containing essential oil (EO) blend

\begin{tabular}{|c|c|c|c|c|c|c|c|c|c|c|c|c|}
\hline \multirow{3}{*}{$\begin{array}{l}\text { EO blend in WPC } \\
\text { films }(w / w) \\
0 \%\end{array}$} & \multicolumn{10}{|c|}{ Light transmission (\%) at different wavelengths (nm) } & \multirow{2}{*}{\multicolumn{2}{|c|}{ Transparency }} \\
\hline & \multirow{2}{*}{$\begin{array}{l}200 \\
0\end{array}$} & \multirow{2}{*}{$\begin{array}{l}250 \\
0\end{array}$} & \multirow{2}{*}{$\begin{array}{l}280 \\
0\end{array}$} & \multirow{2}{*}{$\begin{array}{l}300 \\
0\end{array}$} & \multirow{2}{*}{$\begin{array}{l}350 \\
6.3\end{array}$} & \multirow{2}{*}{$\frac{400}{16.2}$} & \multirow{2}{*}{$\begin{array}{l}500 \\
31.3\end{array}$} & \multirow{2}{*}{$\begin{array}{l}600 \\
37.7\end{array}$} & \multirow{2}{*}{$\frac{700}{40.6}$} & \multirow{2}{*}{$\frac{800}{44.2}$} & & \\
\hline & & & & & & & & & & & 1.421 & $\pm 0.070^{b}$ \\
\hline $2 \%$ & 0 & 0 & 0 & 0 & 0 & 0 & 19.7 & 33.6 & 39.2 & 42.7 & 1.363 & $\pm 0.116^{\mathrm{BC}}$ \\
\hline $2.7 \%$ & 0 & 0 & 0 & 0 & 0 & 0 & 16.6 & 31.1 & 36.3 & 40.1 & 1.422 & $\pm 0.022^{b}$ \\
\hline
\end{tabular}

Mean \pm standard deviation $(n=3)$. Different superscript letters within the same column indicate significant differences from each other $(P<0.05)$.

TABLE 3 Color parameters of whey protein films containing different contents of essential oil (EO) blend

\begin{tabular}{|c|c|c|c|c|c|}
\hline $\begin{array}{l}\text { EO blend in } \\
\text { WPC film }(w / w)\end{array}$ & L* (lightness) & $\begin{array}{l}a^{*}(\text { red }(+a) \text { or } \\
\text { green }(-a))\end{array}$ & $\begin{array}{l}b^{*} \text { (yellow }(+b) \\
\text { or blue }(-b))\end{array}$ & $\begin{array}{l}\Delta \mathrm{E} \text { (total difference } \\
\text { in color) }\end{array}$ & $\begin{array}{l}\text { WI (whiteness } \\
\text { index) }\end{array}$ \\
\hline $0 \%$ & $39.73 \pm 0.46^{a}$ & $-1.41 \pm 0.15^{d}$ & $1.03 \pm 0.02^{c}$ & - & $39.69 \pm 0.44^{a}$ \\
\hline $1 \%$ & $34.71 \pm 1.12^{b}$ & $-1.63 \pm 0.17^{d}$ & $17.57 \pm 0.73^{b}$ & $16.36 \pm 0.69^{a}$ & $30.90 \pm 0.76^{\mathrm{cd}}$ \\
\hline $2 \%$ & $35.23 \pm 0.78^{b}$ & $1.90 \pm 0.19^{c}$ & $18.48 \pm 0.48^{a b}$ & $17.85 \pm 0.58^{b}$ & $32.63 \pm 0.80^{B C}$ \\
\hline $2.7 \%$ & $34.02 \pm 1.16^{b}$ & $4.22 \pm 0.35^{b}$ & $17.57 \pm 0.66^{b}$ & $18.77 \pm 0.59^{c}$ & $30.02 \pm 1.25^{d}$ \\
\hline $5 \%$ & $35.05 \pm 0.95^{b}$ & $7.44 \pm 0.35^{a}$ & $19.21 \pm 0.86^{a}$ & $20.27 \pm 0.43^{c}$ & $33.37 \pm 1.59^{b}$ \\
\hline
\end{tabular}

Mean \pm standard deviation $(n=3)$. Different superscript letters within the same column indicate significant differences from each other $(P<0.05)$. 
property for UV light (range of 200-280 nm) owing to their high content of aromatic amino acids, such as phenylalanine, tryptophan, and tyrosine ${ }^{62}$ that absorb UV light. ${ }^{63}$ Lower barrier for light transmission in UV range was exhibited for fish myofibrillar protein-based film ${ }^{64}$ and for biocomposite film based on fish and chitosan. ${ }^{65}$ Synthetic films show weak properties as UV light barriers such as polyvinyl alcohol (PVOH), ${ }^{64}$ oriented polypropylene (OPP), low-density PE (LDPE), ${ }^{28,53,66}$ polyvinylidene chloride (PVDC), ${ }^{28}$ and Nylon 6,6 $6^{67}$ except for polyester, ${ }^{28,43}$ and PE terephthalate (PET). ${ }^{66}$

In the visible light range $(300-800 \mathrm{~nm})$, the light transmission reduced with increasing EO concentration. This decrease may be due to light scattering of lipid droplets distributed throughout the protein network. $^{25,68}$ Film incorporated with $5 \%$ of EO blend exhibited the highest barrier properties in the visible light. Light transmission values obtained control for film were lower than those reported by Gounga et al $(2007)^{28}$ and Ramos et al $(2013)^{43}$ for whey protein isolate (WPI) and WPC films, respectively. Fish gelatin-chitosan biocomposite films incorporated with oregano EO $(0.4,0.8 \text {, and } 1.2 \%)^{69}$ and fish skin gelatin film incorporated with ginger, turmeric, and plai EO $(25,50$, and $100 \%$, based on protein content) ${ }^{25}$ exhibited lower barrier to visible light than those shown in this study. EOs and their concentration influenced the light transmission values. The results suggest that WPC film incorporated with EOs can retard lipid oxidation and prevent nutrient losses, discoloration, and off-flavour in food systems.

Transparency values showed that EO content has significantly $(P>0.05)$ affected the transparency of film (Table 2). Film incorporated with $5 \%(w / w)$ of EO blend presented the lowest transparency. This result is in agreement with visual observation and in accordance with Hosseini et al (2015), which also related lower transparency with high EO content. ${ }^{69}$ Films based on fish gelatin and chitosan with oregano EO showed lower transparency than those developed in the present study. ${ }^{69}$ On the hand, films with WPI were more transparent than films with WPC. 43

Color change of films due to the addition of EOs can be evaluated in Table 3. The obtained results indicate that all the films exhibit low lightness $\left(L^{*}\right)$. The film without EOs, as can be observed, was clearer than films with EOs, presenting the highest $L$ value. In addition, EO blend affected the color of films, and whiteness and lightness decreased significantly $(P<0.05)$ when adding EOs in the whey protein film. However, $a^{*}$ and $b^{*}$ color parameters increased significantly $(P<0.05)$ in the presence of EO. The characteristic yellowish color of WPC-based films tends to increase with the addition of increasing concentrations of EO blend, due to its characteristic color. WP5 exhibited significantly different redness among WP1, WP2, and WP2.7. These results were consistent with visual observation. The values of total color difference $(\Delta \mathrm{E})$ with respect to the control film, increased significantly $(P<0.05)$ with increased EO blend concentration.

Whiteness index $(\mathrm{Wl})$ showed significant difference $(P<0.05)$ when EOs were incorporated in WP film. A reduction in the WI values was observed with addition of EOs. However, statistical differences were not observed $(P>0.05)$ when EO blend level increased in the WP film. The concentration of the proteins and glycerol in the formation film solution (FFS) did not affect the color of films possibly because the relation of dried solids by surface of films was maintained constant after drying. ${ }^{70}$
These results suggested that the incorporation of EOs influenced film color contributing for the intensification of color. However, there are changes that depended on the type and concentrations of EOs incorporated.

\subsection{4 | Mechanical properties}

Mechanical properties of packaging films are important to maintain their integrity during storage and handling. ${ }^{71}$ Mechanical parameters, TS, and EB were studied and are resumed in Table 4. Fractures took place very rapidly, which were because the films were brittle and weak. The data agree with SEM images that showed cracks in the microstructure of films, which are responsible for the less strong and tough of whey protein films.

Control film presented the lowest TS values $(0.068 \mathrm{MPa})$ and the highest EB values (0.841\%), exhibiting weaker but flexible structure, than films with EO blend. It is suggested that the high water content in control film, besides glycerol, which acts as plasticizer, helps flexibility as reported by Osés et al (2009)..$^{72}$

Addition of EO blend at 1, 2, and $2.7 \%(\mathrm{w} / \mathrm{w})$ caused a significant $(P<0.05)$ increase in the mechanical force (ie, increase TS) reduction in the extensibility (ie, reduced EB) when compared with the control film (without oil), making films less brittle. It created stronger structures but did not improve the film's extensibility. The same tendency was reported by Galus and Kadzinska (2016) on whey protein films incorporated with almond and walnut EOs, at $0.5 \%$ of almond and walnut EOs in protein film. ${ }^{3}$ It may be, probably, due to the low EO blend content incorporated because WP5 exhibited an opposite behavior. The plasticizing effect of the lipids in hydrocolloid films depends strongly on lipid concentration. This may also be related with the homogenization process in which the occurring forces caused the reorganization of the protein matrix. ${ }^{3}$ Besides, the type of EO also showed influence on the mechanical properties of films due their lipid composition, as well as the interaction between the WP and lipid particles as a crosslinking effect. $^{3,73}$

The addition of EO blend at a level of $5 \%(w / w)$ to whey protein film produced the highest heterogeneous and cracked structure, which was demonstrated by SEM image. It caused a decrease of TS in this film, weakening the film structure, and on the other hand, increases the flexibility compared with WP1, WP2, and WP2.7, due to their plasticizer effect.

Besides, lipid addition induces the development of a heterogeneous film structure, featuring discontinuities induced in the protein

TABLE 4 Mechanical properties of whey protein films containing essential oil (EO) blend

\begin{tabular}{lllll}
$\begin{array}{l}\text { EO blend in } \\
\text { WPC film, w/w }\end{array}$ & \multicolumn{2}{l}{$\begin{array}{l}\text { Tensile strength, } \\
\mathrm{MPa}\end{array}$} & \multicolumn{2}{l}{ Elongation at break, \% } \\
\hline $0 \%$ & 0.068 & $\pm 0.005^{\mathrm{d}}$ & 0.841 & $\pm 0.039^{\mathrm{a}}$ \\
$1 \%$ & 0.104 & $\pm 0.006^{\mathrm{c}}$ & 0.171 & $\pm 0.022^{\mathrm{d}}$ \\
$2 \%$ & 0.133 & $\pm 0.016^{\mathrm{b}}$ & 0.111 & $\pm 0.011^{\mathrm{d}}$ \\
$2.7 \%$ & 0.212 & $\pm 0.001^{\mathrm{a}}$ & 0.376 & $\pm 0.018^{\mathrm{c}}$ \\
$5 \%$ & 0.043 & $\pm 0.004^{\mathrm{d}}$ & 0.716 & $\pm 0.012^{\mathrm{b}}$ \\
\hline
\end{tabular}

Values represent the mean \pm standard deviation. Different superscript letters in a same column are significantly different $(P<0.05)$ 
matrix by oil droplets, which provoke a loss of the film cohesion and mechanical resistance. The latter may affect the stretching ability of the film. ${ }^{46,74}$ Similar behavior was observed by Tongnuanchan et al (2013), Bahram et al (2014), Martucci et al (2015), and Shen and Kamdem (2015) that have mentioned that oil addition to film formulation tends to weaken the film ${ }^{2,25,61,75}$ but also can increase flexibility. ${ }^{3}$

In general, the presence of EO in the film can lead to the formation of a weak network structure, resulting in reduced TS and increased EB. ${ }^{47}$ This occurs because there is a partial replacement of stronger polymer-polymer interactions by weaker polymer-oil interactions in the film network, when EO components are present. ${ }^{61}$

The presence of phenolic compounds in EO blend may result in protein crosslinking during the film casting which may partially account for the increase in mechanical strength. However, TS decreased as the lipid droplet size in the films increased as observed when added $5 \%$ of EO blend. ${ }^{76}$

According to Ramos et al (2013), rising plasticizer content increases film elongation because it constrains the establishment of hydrogen bonds between the protein chains, thus increasing intermolecular spacing, and therefore chain mobility. ${ }^{45}$ Additionally, as reported by Bonilla et al (2012), the interruption of the polymer chain aggregation in the matrix by the presence of oil favors the sliding of the chains during film stretching, contributing for plastic behavior. ${ }^{46}$

Due to the differences in the interacting with polymer network, different EOs affected the mechanical properties (resistance to elongation and capacity for stretching) of the films differently, as suggested by Martucci et al $(2015)^{75}$ and Shen and Kamdem (2015). ${ }^{61}$ Differences in the results may also be attributed to the concentration of protein, humidity, and experimental conditions. ${ }^{2,74}$

\subsection{Effectiveness of the whey protein active films}

\subsection{1 | Optimization and validation the method to deter- mine hexanal}

The results of the validation of the method to determine hexanal are resumed in Table 5. Analytical curve was linear over the concentration range (0.05-20 $\left.\mathrm{\mu g} \mathrm{mL}^{-1}\right)$. Calibration data presented high determination coefficient ( $\geq 0.999$ ), indicating suitability for quantification.

The Guidelines of the American Chemical Society (ACS) were used to determine detection limits (defined as the signal 3 times the height of the noise level). ${ }^{77}$ LOD and LOQ of hexanal are shown in Table 5.

TABLE 5 Validation data for the UHPLC-DAD method for determination of hexanal in meat products

\begin{tabular}{|c|c|}
\hline Analytical curve equation & $y=204201.34 x+6296.08$ \\
\hline Determination coefficient $\left(r^{2}\right)$ & 0.999 \\
\hline Linear range $\left(\mu \mathrm{g} \mathrm{mL}^{-1}\right)$ & $0.05-20$ \\
\hline LOD (ng mL ${ }^{-1}$ ) & 25 \\
\hline $\mathrm{LOQ}\left(\mathrm{ng} \mathrm{mL}{ }^{-1}\right.$ ) & 50 \\
\hline Intra-day precision $(n=6)(\%$ RSD) & 4.84 \\
\hline Inter-day precision ( $n=12)(\%$ RSD) & 4.73 \\
\hline Amount recovered $\left(\mu \mathrm{g} \mathrm{mL^{-1 } )}\right.$ & 0.54 \\
\hline Recovery (\%) $(n=6)$ & 111.7 \\
\hline
\end{tabular}

Abbreviations: LOD, limit of detection; LOQ, limit of quantification; RSD, relative standard deviation.
Most of the times hexanal is determined by gas chromatography. However, it is possible to find some studies with LC, such as Veloso et al (2001), ${ }^{78} \mathrm{Xu}$ et al (2010), ${ }^{79}$ Song et al (2011), ${ }^{80}$ and Zhu et al (2013). ${ }^{81}$ Theses authors found a LOD for hexanal of $2.19 \mathrm{mmol} \mathrm{mg}$ ${ }^{-1}, 0.79 \mathrm{nmol} \mathrm{L}^{-1}, 1.87 \mathrm{mmol} \mathrm{L}^{-1}$, and $1.6 \mu \mathrm{g} \mathrm{kg}^{-1}$, respectively. Lower LOD ( $9 \mathrm{ng} \mathrm{mL}^{-1}$ ) than those shown in this study were found for hexanal by reversed-phase high-performance liquid chromatographic technique (HPLC) method. ${ }^{18}$

The same sample was analyzed over 3 consecutive days, using the same reagents and apparatus, to evaluate method intraday and interday precision on the basis of the relative standard deviation (RSD) of hexanal. Intraday and interday precision of the method (expressed as RSD) were lower than $5 \%$. The results revealed a good recovery (111.72\%), as shown in Table 5.

\subsubsection{Evaluation of active film effectiveness against lipid oxidation}

The determination of the oxidation degree was carried out in the packaged salami with whey protein films containing the EO blend and after $4,7,15,30,45,60,90,135$, and 180 days of storage at $5{ }^{\circ} \mathrm{C}$. The results are presented in Figures 3 and 4 .

At all times of storage, the salami exhibited no apparent deterioration, not even over the 180 days of storage. The strong distinctive aroma of cinnamon EO (present in the blend) was noticed in the salami packaged with the active WPC-. Visually, the salami did not present physical alteration. Although the active film presented a yellowish coloration, it did not alter the coloration of the packaged salami slices.

During the first days of storage, the level of hexanal increased significantly for all the films except for $\mathrm{WP}_{5}$ (Figure 3). The amount of hexanal in the salami packaged with WP5 was below the limit of quantification after 7, 30, and 45 days of storage.

At 45 days of storage, it was not observed a significative difference $(P>0.05)$ among the films, while at 135 days, the WP1 and WP5 of EO blend presented the lowest hexanal values and there was no significative differences $(P>0.05)$ between them. The film with $5 \%$ of EO blend was the most effective, showing a significative difference $(P<0.05)$ when compared with the control film (without EO), and the WP1, WP2, and WP2.7 at 180 days of storage. However, after longer storage periods (135 and 180 days), all the films were effective, adding protection to meat against lipid oxidation.

TBARS content of the salami packaged with whey protein film incorporated EO blend, at different concentrations, is presented in Figure 4.

The results showed that the films incorporating EOs significantly reduced the oxidation status. Until 60 days of storage, the WP1 did not present significative differences $(P>0.05)$ when compared with the control film (without EOs). However, regarding the active films, it showed lower amount of MDA. For longer storage periods (90, 135, and 180 days), all active films were effective against lipid oxidation in comparison with control film, and no significative differences $(P>0.05)$ among them at 90 and 180 days was noticed.

In the last few years, some studies have evaluated the influence of EOs in the organoleptic characteristics of foods. For instance, Gutierrez et al (2009) ${ }^{82}$ carried out a study to optimize the application of EOs for minimally processed vegetables (MPV) decontamination. 
FIGURE 3 Hexanal content of salami stored for 180 days at $5^{\circ} \mathrm{C}$ packaged with whey protein film incorporated with different content of essential oil (EO) blend

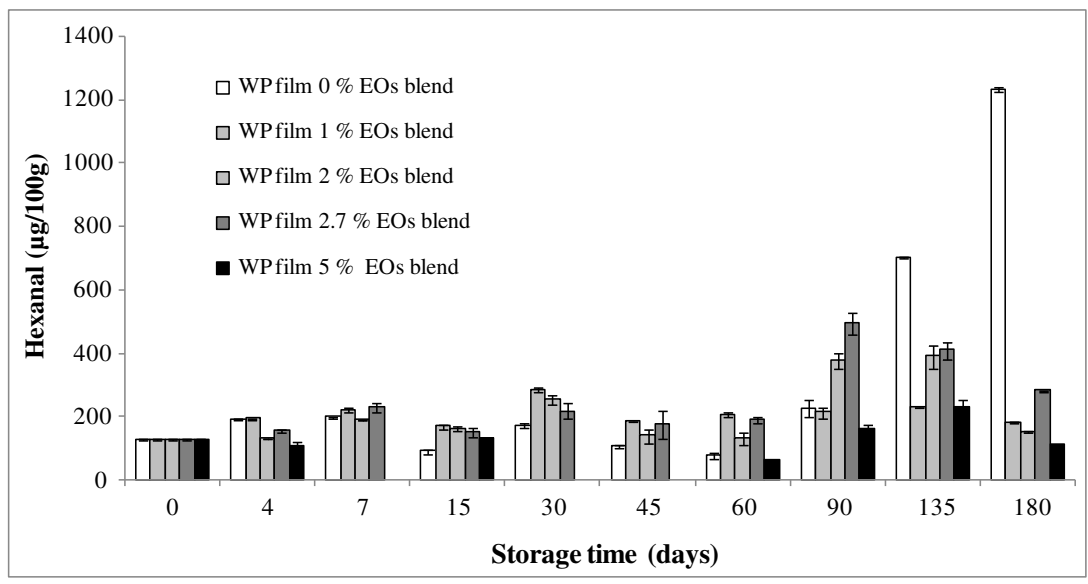

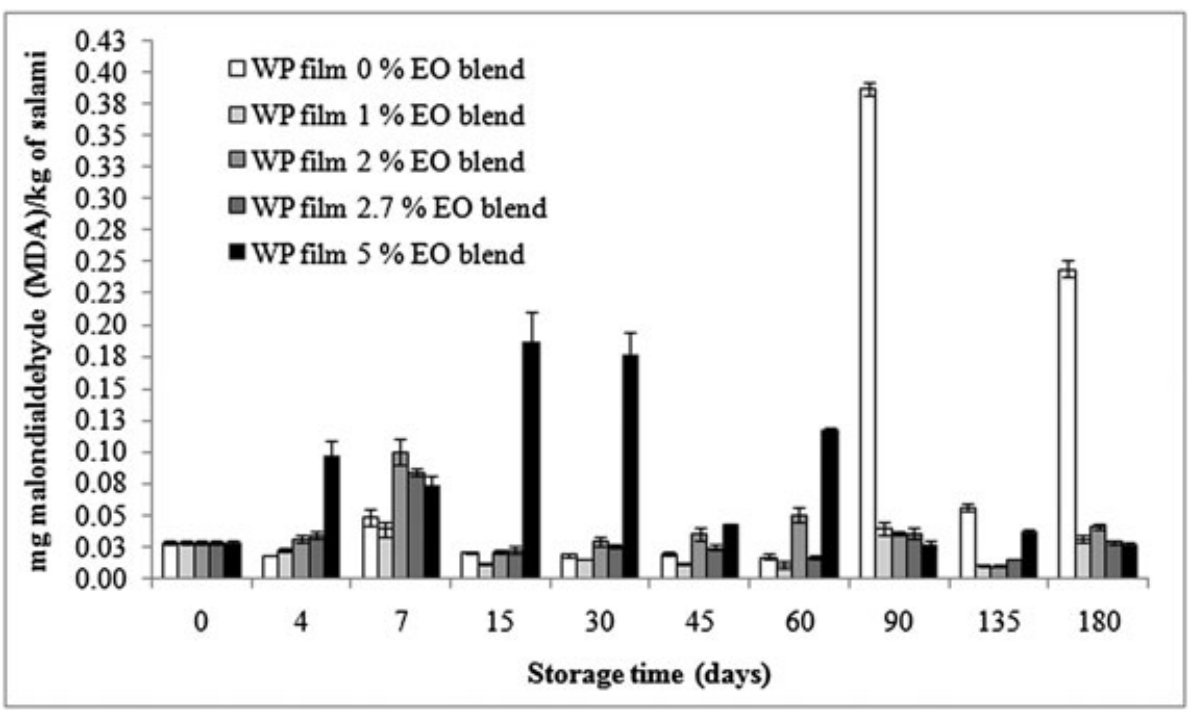

FIGURE 4 Results of TBARS assay applied to salami packaged at $5{ }^{\circ} \mathrm{C}$ with whey protein films incorporated with different concentrations of essential oil (EO) blend for 180 days

Besides control of spoilage microflora and improving shelf life, improvement was addressed as well as organoleptic properties. At the end of the storage period panelists rejected lettuce washed with the EO treatments for overall appreciation. Authors proposed the combination of EOs with other natural preservatives to minimize doses and consequently reduce impact on organoleptic properties of MPV.

Ghabraie et al (2015) ${ }^{83}$ carried out a study to assess the antimicrobial activities of 32 different EOs against 5 different foodborne pathogens and a spoilage bacteria. Further, to select the best combined EOs with high antimicrobial effects for food application, the combined effects of different EOs were evaluated, and sensorial analysis was performed to determine the organoleptically acceptable concentration of selected EO combination directly added on ground meat as a food model. Sensory evaluation of combined Chinese cinnamon and Cinnamon bark EOs used in cooked meat was conducted, and an EO level of $0.05 \%$ was the highest organoleptically acceptable.

Quesada et al (2016) ${ }^{84}$ concluded that thyme odor was perceived as desirable in cooked meat and Catarino and co-authors $(2017)^{85}$ have applied WPC active coating containing Origanum virens EO on the surface of 2 traditional Portuguese sausages during industrial production. The sensory analysis revealed little differences between coated and uncoated sausage attributes, suggesting good acceptance of both. The only parameter that was underscored in coated samples as compared with uncoated ones was aroma. According to panelists, the main reason was the strong oregano scent which they were not familiar with in these products.

The taste of the packaged salami was not evaluated after different storage periods. Based on the literature, we think that although the cinnamon it might be perceived but it would not affect the taste at a level that would cause food rejection because it is used at low levels in the packaging and does not migrate totally to the salami. ${ }^{86}$

Essential oils are complex mixtures whose toxicity depends on the effects among their constituents and it is difficult to predict. ${ }^{87}$ Regarding the EO safety, the serious cases of poisoning from EOs are consequence of ingestion of undiluted EOs in amounts much above therapeutic doses. Some adverse reactions were reported for cinnamon, not always defined as cinnamon bark oil, including cheilitis (from chewing gum), stomatitis, and other oral adverse reactions. In the applied doses, the new active films shall not result in any allergic reactions. ${ }^{88}$

\section{4 | CONCLUSION}

Films incorporating the EO blend were more opaque and with less lightness than control film. The characteristic yellowish color of 
WPC-based films tends to increase with the addition of higher concentrations of EO blend at films' formulation. The incorporation of EOs to whey protein films affected significantly the lightness, MC, SW, WVTR, and CA, exhibiting films more hydrophobic than control film, while thickness does not differ when compared with the control film. However, films with higher content of EO blend showed to have a more hydrophilic behavior. These results were complemented with microstructure analysis, which was observed as a heterogeneous, rough, and porous surface. The addition of an EO blend to whey protein films did not result in films with improved mechanical or barrier properties. Nevertheless, the results also suggest that whey protein film might be able to retard lipid oxidation.

In fact, incorporation of an optimal EO blend demonstrated that the application of bioactive films can reduce the lipid oxidation phenomenon of meat products, extending their shelf life while releasing natural antioxidants to their surface. This shows the possibility of using these natural compounds in packaging food products.

Whey protein is a food packaging material that meets the environmental appeal for recyclable and biodegradable packaging. Moreover, the use of EOs as natural additives promotes consumer health by the reduction or replacement of synthetic additives.

\section{ACKNOWLEDGEMENTS}

This work was supported by the research project "Development of an edible film based on whey protein with antioxidant and antimicrobial activity using essential oils" (2012DAN807) funded by the National Institute of Health Dr Ricardo Jorge, I.P. (Lisbon, Portugal), Carlos Chagas Filho Foundation for Research Support of the State of Rio de Janeiro (FAPERJ), and National Council for Scientific Research (CNPq). Regiane Ribeiro dos Santos (BEX 8754/14-4) is grateful for her research grant funded by Brazilian Federal Agency for Support and Evaluation of Graduate Education (CAPES).

\section{ORCID}

Ana Sanches-Silva 1 http://orcid.org/0000-0002-0226-921X

\section{REFERENCES}

1. Coles R, McDowell D, Kirwan MJ, editors. Food Packaging Technology. Blackwell Publishing Ltd; 2003. 273p.

2. Bahram S, Rezaei M, Soltani M, Kamali A, Ojagh SM, Abdollahi M. Whey protein concentrate edible film activated with cinnamon essential oil. Journal of Food Processing and Preservation. 2014;38(3):12511258. https://doi.org/10.1111/jfpp.12086

3. Galus S, Kadzińska J. Whey protein edible films modified with almond and walnut oils. Food Hydrocoll. 2016;52:78-86. https://doi.org/ 10.1016/j.foodhyd.2015.06.013

4. European Commission. Regulation (EC) No. 450/2009. Off J Eur Union 2009;:L135(450):3-11.

5. European Commission. Regulation (EC) No 1935/2004. Off J Eur Union. 2004;L338/4(1935):4-17

6. Sanches-Silva A, Costa HS, Losada PP, et al. Preparation of active packaging with antioxidant and antimicrobial activity based on astaxanthin and chitosan. Nutrition Bulletin. 2010;35(3):268-271. https://doi.org/ 10.1111/j.1467-3010.2010.01834.x

7. Sanches-Silva A, Costa D, Albuquerque TG, et al. Trends in the use of natural antioxidants in active food packaging: a review. Food Additives
\& Contaminants: Part A. 2014;31(3):374-395. https://doi.org/ 10.1080/19440049.2013.879215

8. Ud-Daula AFMS, Demirci F, Abu Salim K, et al. Chemical composition, antioxidant and antimicrobial activities of essential oils from leaves, aerial stems, basal stems, and rhizomes of Etlingera fimbriobracteata (K.Schum.) R.M.Sm. Industrial Crops and products. 2016;84:189-198. https://doi.org/10.1016/j.indcrop.2015.12.034

9. Patrignani F, Siroli L, Serrazanetti DI, Gardini F, Lanciotti R. Innovative strategies based on the use of essential oils and their components to improve safety, shelf-life and quality of minimally processed fruits and vegetables. Trends in Food Science and Technology. 2015;46(2):311319. https://doi.org/10.1016/j.tifs.2015.03.009

10. Ribeiro-Santos R, Andrade M, Melo NR, et al. Biological activities and major components determination in essential oils intended for a biodegradable food packaging. Industrial Crops and Products. 2017;97:201210. https://doi.org/10.1016/j.indcrop.2016.12.006

11. Karre L, Lopez K, Getty KJK. Natural antioxidants in meat and poultry products. Meat Sci. 2013;94(2):220-227. https://doi.org/10.1016/j. meatsci.2013.01.007

12. Food And Drug Administration (FDA). (2016). Code of Federal Regulations (CFR). Title 21: Food and Drugs. Chapter I-Food and Drug Administration, Department of Health and Human Services, Subchapter B-Food for Human Consumption (Continued), Part 182-Substances Generally Recognized as Safe (GRAS), Subpart A-General Provisions, Subpart 182.20-Essential oils, oleoresins, and natural extractives. Office of the Federal Register, Washington, (Revised April, 2016).

13. European Commission. Commission Directive 2010/67/EU. Off J Eur Union. 2010;17-26.

14. European Commission. Commission Directive 2010/69/EU. Off J Eur Union. 2010;22-31.

15. Ribeiro-Santos R, Carvalho-Costa D, Cavaleiro C, et al. A novel insight on an ancient aromatic plant: The rosemary (Rosmarinus officinalis L.). Trends in Food Science and Technology. 2015;45(2):355-368. https:// doi.org/10.1016/j.tifs.2015.07.015

16. McClements DJ, Decker EA. Lipid oxidation in oil-in-water emulsions: impact of molecular environment on chemical reactions in heterogeneous food systems. J Food Sci. 2000;65(8):1270-1282. https://doi. org/10.1111/j.1365-2621.2000.tb10596.x/abstract

17. Guyon C, Meynier A, de Lamballerie M. Protein and lipid oxidation in meat: a review with emphasis on high-pressure treatments. Trends in Food Science and Technology. 2016;50:131-143. https://doi.org/ 10.1016/j.tifs.2016.01.026

18. Ross CF, Smith DM. Use of volatiles as indicators of lipid oxidation in muscle foods. Comprehensive Reviews in Food Science and Food Safety. 2006;5(1):18-25. https://doi.org/10.1111/j.1541-4337.2006.tb00077.x

19. Sanches-Silva A, Rodríguez-Bernaldo de Quirós A, López-Hernández J, Paseiro-Losada P. Determination of hexanal as indicator of the lipidic oxidation state in potato crisps using gas chromatography and highperformance liquid chromatography. J Chromatogr A. 2004;1046(12):75-81. https://doi.org/10.1016/j.chroma.2004.06.101

20. Sanches-Silva A, López-Hernández J, Paseiro-Losada P. Profiling flavor compounds of potato crisps during storage using solid phase microextraction. J Chromatogr A. 2005;1064:239-245.

21. Oussalah M, Caillet S, Salmiéri S, Saucier L, Lacroix M. Antimicrobial and antioxidant effects of milk protein-based film containing essential oils for the preservation of whole beef muscle. J Agric Food Chem. 2004;52(18):5598-5605.

22. Oussalah M, Caillet S, Salmiéri S, Saucier L, Lacroix M. Antimicrobial effects of alginate-based films containing essential oils on Listeria monocytogenes and Salmonella typhimurium present in bologna and ham. J Food Prot. 2007;70(4):901-908.

23. Gómez-Estaca J, López de Lacey A, López-Caballero ME, GómezGuillén MC, Montero P. Biodegradable gelatin-chitosan films incorporated with essential oils as antimicrobial agents for fish preservation. Food Microbiol. 2010;27(7):889-896. 
24. Melo AAM de, Geraldine RM, Silveira MFA, Torres MCL, Rezende CSM e, Fernandes TH, et al. Microbiological quality and other characteristics of refrigerated chicken meat in contact with cellulose acetate-based film incorporated with rosemary essential oil. Braz J Microbiol 2012; 43(4), pp. 1419-1427. https://doi.org/10.1590/S1517-83822012000400025

25. Tongnuanchan P, Benjakul S, Prodpran T. Physico-chemical properties, morphology and antioxidant activity of film from fish skin gelatin incorporated with root essential oils. J Food Eng. 2013;117(3):350-360. https://doi.org/10.1016/j.jfoodeng.2013.03.005

26. Peng Y, Li Y. Combined effects of two kinds of essential oils on physical, mechanical and structural properties of chitosan films. Food Hydrocoll. 2014;36:287-293. https://doi.org/10.1016/j.foodhyd.2013.10.013

27. Ribeiro-Santos R, Sanches-Silva A, Motta JFM, et al. Combined use of essential oils applied to protein base active food packaging: study in vitro and in a food simulant. Eur Polym J. In Press;

28. Gounga ME, Xu S-Y, Wang Z. Whey protein isolate-based edible films as affected by protein concentration, glycerol ratio and pullulan addition in film formation. J Food Eng. 2007;83(4):521-530. https://doi. org/10.1016/j.jfoodeng.2007.04.008

29. Han JH, Floros JD. Casting antimicrobial packaging films and measuring their physical properties and antimicrobial activity. Journal of Plastic Film and Sheeting. 1997;13:287-298.

30. Phan TD, Debeaufort F, Luu D, Voilley A. Functional properties of edible agar-based and starch-based films for food quality preservation. J Agric Food Chem. 2005;53(4):973-981. https://doi.org/10.1021/jf040309s

31. Tang $\mathrm{C}-\mathrm{H}$, Jiang Y. Modulation of mechanical and surface hydrophobic properties of food protein films by transglutaminase treatment. Food Res Int. 2007;40(4):504-509. https://doi.org/10.1016/j.foodres.2006.09.010

32. Galus S, Lenart A, Voilley A, Debeaufort F. Effect of oxidized potato starch on the physicochemical properties of soy protein isolate-based edible films. Food Technology and Biotechnology. 2013;51(3):403-409.

33. Vogler EA. Structure and reactivity of water at biomaterial surfaces. Adv Colloid Interface Sci. 1998;74(1-3):69-117. https://doi.org/ 10.1016/S0001-8686(97)00040-7

34. American Society for Testing and Materials (ASTM). Standard Test Method for Water Vapor Transmission of Materiais. Philadelphia, PA: Annual book of ASTM standards; 2000 p. ASTM E96-00.

35. American Society for Testing and materials-ASTM. Standard Test Method for Tensile Properties of Thun Plastic Sheeting. Philadelphia, PA:ASTM D882-02: Annual book of ASTM standards; 2002:1-9.

36. Herranz B, Ordóñez JA, De La Hoz L, Hierro E, Soto E, Cambero MI. Fatty acid composition of salami from different countries and their nutritional implications. International Journal of Food Science and Nutrition. 2008;59(7-8):607-618. https://doi.org/10.1080/09513590701550270

37. Sarantópoulos CIGL, Oliveira LM, Padula M, Coltro L, Alves RMV, Garcia EEC. Embalagens Plasticas Flexíveis: Principais polímeros e avaliação de propriedades. CETEA/ITAL; 2002, 267.

38. Wen J, Morrissey PA, Walton J, Sheehy PJA. Rapid and quantitative determination of hexanal in cooked muscle foods. Irish Journal of Agricultural and Food Research. 1997;36(1):75-84.

39. ICH (International Conference on Harmonization). Guidance for industry Q2b: validation of analytical procedures: methodology. Rockv US FDA Fed Regist. 1997;

40. Miller DD. Food Chemistry: A Laboratory Manual. 2nd ed. Wiley; 1998.

41. Kokoszka S, Debeaufort F, Lenart A, Voilley A. Water vapour permeability, thermal and wetting properties of whey protein isolate based edible films. Int Dairy J. 2010;20(1):53-60. https://doi.org/10.1016/j. idairyj.2009.07.008

42. Ramos ÓL, Silva SI, Soares JC, et al. Features and performance of edible films, obtained from whey protein isolate formulated with antimicrobial compounds. Food Res Int. 2012;45(1):351-361. https://doi.org/ 10.1016/j.foodres.2011.09.016

43. Ramos ÓL, Reinas I, Silva SI, et al. Effect of whey protein purity and glycerol content upon physical properties of edible films manufactured therefrom. Food Hydrocoll. 2013;30(1):110-122. https://doi.org/ 10.1016/j.foodhyd.2012.05.001

44. Anker M, Stading M, Hermansson A-M. Relationship between the microstructure and the mechanical and barrier properties of whey protein films. J Agric Food Chem. 2000;48(9):3806-3816. https://doi.org/ 10.1021/jf000040m

45. Jouki M, Yazdi FT, Mortazavi SA, Koocheki A. Quince seed mucilage films incorporated with oregano essential oil: physical, thermal, barrier, antioxidant and antibacterial properties. Food Hydrocoll. 2014;36:9-19. https://doi.org/10.1016/j.foodhyd.2013.08.030

46. Bonilla J, Atarés L, Vargas M, Chiralt A. Effect of essential oils and homogenization conditions on properties of chitosan-based films. Food Hydrocoll. 2012;26(1):9-16. https://doi.org/10.1016/j.foodhyd.2011. 03.015

47. Atef M, Rezaei M, Behrooz R. Characterization of physical, mechanical, and antibacterial properties of agar-cellulose bionanocomposite films incorporated with savory essential oil. Food Hydrocoll. 2014;45:150157. https://doi.org/10.1016/j.foodhyd.2014.09.037

48. Le Tien C, Letendre M, Ispas-Szabo P, et al. Development of biodegradable films from whey proteins by cross-linking and entrapment in cellulose. J Agric Food Chem. 2000;48(11):5566-5575. https://doi.org/ 10.1021/jf0002241

49. Schmidt V, Giacomelli C, Soldi V. Thermal stability of films formed by soy protein isolate-sodium dodecyl sulfate. Polym Degrad Stab. 2005;87(1):25-31. https://doi.org/10.1016/j.polymdegradstab.2004. 07.003

50. Barbosa LCA. In: UFV E, ed. editorEspectroscopia no infravermelho na caracterização de compostos orgânicos. Viçosa; 2007189 p.

51. Bandekar J. Amide modes and protein conformation. Biochimica et Biophysica Acta (BBA)-Protein Structure and Molecular Enzymology. 1992;1120(2):123-143.

52. Pereira RN, Souza BWS, Cerqueira MA, Teixeira JA, Vicente AA. Effects of electric fields on protein unfolding and aggregation: influence on edible films formation. Biomacromolecules. 2010;11(11):2912-2918. https://doi.org/10.1021/bm100681a

53. Lodha P, Netravali AN. Thermal and mechanical properties of environment-friendly "green" plastics from stearic acid modified-soy protein isolate. Industrial Crops and products. 2005;21(1):49-64. https://doi. org/10.1016/j.indcrop.2003.12.006

54. Ojagh SM, Rezaei M, Razavi SH, Hosseini SMH. Development and evaluation of a novel biodegradable film made from chitosan and cinnamon essential oil with low affinity toward water. Food Chem. 2010;122(1):161-166. https://doi.org/10.1016/j.foodchem.2010.02.033

55. Atarés L, De Jesús C, Talens P, Chiralt A. Characterization of SPI-based edible films incorporated with cinnamon or ginger essential oils. J Food Eng. 2010;99(3):384-391. https://doi.org/10.1016/j.jfoodeng.2010. 03.004

56. Wang L-J, Yin Y-C, Yin S-W, et al. Development of novel zein-sodium caseinate nanoparticle (ZP)-stabilized emulsion films for improved water barrier properties via emulsion/solvent evaporation. J Agric Food Chem. 2013;61(46):11089-11097. https://doi.org/10.1021/jf4029943

57. Teixeira B, Marques A, Pires C, et al. Characterization of fish protein films incorporated with essential oils of clove, garlic and origanum: physical, antioxidant and antibacterial properties. LWT-Food Science and Technology. 2014;59(1):533-539. https://doi.org/10.1016/j. Iwt.2014.04.024

58. Kim S-J, Ustunol Z. Solubility and moisture sorption isotherms of wheyprotein-based edible films as influenced by lipid and plasticizer incorporation. J Agric Food Chem. 2001;49(9):4388-4391. https://doi.org/ 10.1021/jf010122q

59. Sánchez-González L, Cháfer M, Chiralt A, González-Martínez C. Physical properties of edible chitosan films containing bergamot essential oil and their inhibitory action on Penicillium italicum. Carbohydr Polym. 2010;82(2):277-283. https://doi.org/10.1016/j.carbpol.2010.04.047

60. Aguirre A, Borneo R, León AE. Antimicrobial, mechanical and barrier properties of triticale protein films incorporated with oregano essential 
oil. Food Bioscience. 2013;1:2-9. https://doi.org/10.1016/j. fbio.2012.12.001

61. Shen Z, Kamdem DP. Development and characterization of biodegradable chitosan films containing two essential oils. Int J Biol Macromol. 2015;74:289-296. https://doi.org/10.1016/j.ijbiomac.2014.11.046

62. Ribeiro-Santos R, Souza ALS, Trombete FM, Melo NR. Proteína do soro de leite: Aproveitamento e aplicações na produção de embalagem biodegradável. Revista Verde de Agroecologia e Desenvolvimento Sustentável. 2015b;10(5):51-58.

63. Schmid F-X. Biological Macromolecules: UV-visible Spectrophotometry. In: Encyclopedia of Life Sciences. John Wiley \& Sons, Ltd: Chichester, UK; 2001.

64. Limpan N, Prodpran T, Benjakul S, Prasarpran S. Properties of biodegradable blend films based on fish myofibrillar protein and polyvinyl alcohol as influenced by blend composition and pH level. J Food Eng. 2010;100(1):85-92. https://doi.org/10.1016/j.jfoodeng.2010.03.031

65. Hosseini SF, Rezaei M, Zandi M, Ghavi FF. Preparation and functional properties of fish gelatin-chitosan blend edible films. Food Chem. 2013;126:1490-1495.

66. Farris S, Introzzi L, Piergiovanni L. Evaluation of a bio-coating as a solution to improve barrier, friction and optical properties of plastic films. Packaging Technology and Science. 2009;22(2):69-83. https://doi.org/ 10.1002/pts.826

67. Fang Y, Tung MA, Britt IJ, Yada S, Dalgleish DG. Tensile and barrier properties of edible films made from whey proteins. J Food Sci. 2002;67(1):188-193. https://doi.org/10.1111/j.1365-2621.2002. tb11381.x

68. Tongnuanchan P, Benjakul S, Prodpran T. Properties and antioxidant activity of fish skin gelatin film incorporated with citrus essential oils. Food Chem. 2012;134(3):1571-1579. https://doi.org/10.1016/j. foodchem.2012.03.094

69. Hosseini SF, Rezaei M, Zandi M, Farahmandghavi F. Bio-based composite edible films containing Origanum vulgare L. essential oil. Industrial Crops and products. 2015;67:403-413. https://doi.org/10.1016/j. indcrop.2015.01.062

70. Sobral PJ do A, dos Santos JS, García FT. Effect of protein and plasticizer concentrations in film forming solutions on physical properties of edible films based on muscle proteins of a Thai Tilapia. $J$ Food Eng 2005; 70(1), pp. 93-100. https://doi.org/10.1016/j. jfoodeng.2004.09.015

71. Oymaci P, Altinkaya SA. Improvement of barrier and mechanical properties of whey protein isolate based food packaging films by incorporation of zein nanoparticles as a novel bionanocomposite. Food Hydrocoll. 2016;54:1-9. https://doi.org/10.1016/j.foodhyd.2015.08.030

72. Osés J, Fabregat-Vázquez M, Pedroza-Islas R, Tomás SA, Cruz-Orea A, Maté Jl. Development and characterization of composite edible films based on whey protein isolate and mesquite gum. J Food Eng. 2009;92(1):56-62. https://doi.org/10.1016/j.jfoodeng.2008.10.029

73. Acevedo-Fani A, Salvia-Trujillo L, Rojas-Graü MA, Martín-Belloso O. Edible films from essential-oil-loaded nanoemulsions: physicochemical characterization and antimicrobial properties. Food Hydrocoll. 2015;47:168-177. https://doi.org/10.1016/j.foodhyd.2015.01.032

74. Zinoviadou KG, Koutsoumanis KP, Biliaderis CG. Physico-chemical properties of whey protein isolate films containing oregano oil and their antimicrobial action against spoilage flora of fresh beef. Meat Sci. 2009;82(3):338-3345. https://doi.org/10.1016/j.meatsci.2009.02.004

75. Martucci JF, Gende LB, Neira LM, Ruseckaite RA. Oregano and lavender essential oils as antioxidant and antimicrobial additives of biogenic gelatin films. Industrial Crops and products. 2015;71:205-213. https://doi.org/10.1016/j.indcrop.2015.03.079

76. Ma W, Tang C-H, Yin S-W, et al. Characterization of gelatin-based edible films incorporated with olive oil. Food Res Int. 2012;49:572-579. https://doi.org/10.1016/j.foodres.2012.07.037

77. American Chemical Society A. The Guidelines of the American Chemical Society (ACS). Anal Chem. 1980;52:2242

78. Veloso MC, da Silva VM, Vieira Santos G, de Andrade JB. Determination of aldehydes in fish by high-performance liquid chromatography. J Chromatogr Sci. 2001;39(5):173-176. https://doi.org/10.1093/ chromsci/39.5.173

79. Xu H, Lv L, Hu S, Song D. High-performance liquid chromatographic determination of hexanal and heptanal in human blood by ultrasoundassisted headspace liquid-phase microextraction with in-drop derivatization. J Chromatogr A. 2010;1217(16):2371-2375. https://doi.org/ 10.1016/j.chroma.2009.09.068

80. Song D, Gu Y, Liang L, Ai Z, Zhang L, Xu H. Magnetic solid-phase extraction followed by high performance liquid chromatography for determination of hexanal and heptanal in human urine. Anal Methods. 2011;3(6):1418. https://doi.org/10.1039/C1AY05102D

81. Zhu H, Li X, Shoemaker CF, Wang SC. Ultrahigh performance liquid chromatography analysis of volatile carbonyl compounds in virgin olive oils. Journal Agricultural and Food Chemistry. 2013;61(50):1225312259. https://doi.org/10.1021/jf404368m

82. Gutierrez J, Bourke P, Lonchamp J, Barry-Ryan C. Impact of plant essential oils on microbiological, organoleptic and quality markers of minimally processed vegetables. Innovative Food Science and Emerging Technologies. 2009;10:195-202. https://doi.org/10.1016/j.ifset.2008. 10.005

83. Ghabraie M, Vu KD, Tata L, Salmieri S, Lacroix M. Antimicrobial effect of essential oils in combinations against five bacteria and their effect on sensorial quality of ground meat. LWT-Food Science and Technology. 2015. https://doi.org/10.1016/j.lwt.2015.10.055

84. Quesada J, Sendra E, Navarro C, Sayas-Barberá E. Antimicrobial active packaging including chitosan films with Thymus vulgaris $L$. essential oil for ready-to-eat meat. Foods. 2016;5(3). https://doi.org/10.3390/ foods 5030

85. Catarino MD, Alves-Silva JM, Fernandes RP, et al. Development and performance of whey protein active coatings with Origanum virens essential oils in the quality and shelf life improvement of processed meat products. Food Control. 2017. https://doi.org/10.1016/j. foodcont.2017.03.054

86. Ribeiro-Santos R, Melo NR, Andrade M, Sanches-Silva A. Potential of migration of active compounds from protein based films with essential oils to a food and a food simulant. Packaging Technology and Science. 2017. https://doi.org/10.1002/pts.2334

87. Tisserand R,Young R. Toxicity. In: Essential Oil Safety. Elsevier 2014, pp. 23-38. https://doi.org/10.1016/B978-0-443-06241-4.00003-5

88. Johnson S, Boren K. Topical and oral administration of essential oilssafety issues. Aromatopia. 2013;22(4):43-48.

How to cite this article: Ribeiro-Santos R, de Melo NR, Andrade $\mathrm{M}$, et al. Whey protein active films incorporated with a blend of essential oils: Characterization and effectiveness. Packag Technol Sci. 2018;31:27-40. https://doi.org/10.1002/pts.2352 